\title{
A Novel Indole-diterpenoid, JBIR-03 with Anti-MRSA Activity from Dichotomomyces cejpii var. cejpii NBRC 103559
}

\author{
Masahiro Ogata, Jun-ya Ueda, Midori Hoshi, Junko Hashimoto, Takuji Nakashima, \\ Kozue Anzai, Motoki Takagi, Kazuo Shin-ya
}

Received: July 20, 2007 / Accepted: September 19, 2007

(C) Japan Antibiotics Research Association

\begin{abstract}
A new indole-diterpene, JBIR-03 (1), was isolated from the fungus Dichotomomyces cejpii var. cejpii NBRC 103559 and its structure was determined based on the spectroscopic data. 1 exhibited anti-MRSA (methicillinresistant Staphylococcus aureus) activity and antifungal activity against apple Valsa canker-causing fungus, Valsa ceratosperma, while it exhibited no toxicity towards human cancer cells.
\end{abstract}

Keywords JBIR-03, indole-diterpene, Dichotomomyces cejpii, MRSA, Valsa ceratosperma

\section{Introduction}

During the past decade, nosocomial infections caused by methicillin-resistant Staphylococcus aureus (MRSA) in hospitals have become a serious clinical problem [1]. Vancomycin has been used for the treatment of infections due to MRSA. However, vancomycin-resistant $S$. aureus has recently been isolated [2]. The emergence of vancomycin-resistant bacterial strains is a very serious public health problem. Therefore, a new anti-MRSA antibiotic is clinically of interest. On the other hand, Valsa

K. Shin-ya (Corresponding author): Biological Information Research Center (BIRC), National Institute of Advanced Industrial Science and Technology (AIST), 2-42 Aomi, Koto-ku, Tokyo 135-0064, Japan, E-mail: k-shinya@aist.go.jp

M. Takagi (Corresponding author), J. Ueda, M. Hoshi, J. Hashimoto: Japan Biological Information Research Center (JBIRC), Japan Biological Informatics Consortium (JBIC), 2-42 Aomi, Koto-ku, Tokyo 135-0064, Japan,

E-mail: motoki-takagi@aist.go.jp canker, caused by the fungus Valsa ceratosperma is a significant disease of apple in the Pacific Rim countries, including Japan, China, and Korea [3]. It is also found occasionally on pear and quince. In northern Japan, the disease is especially severe with more than $35 \%$ of orchards affected to some degree. However, information available to help with breeding against Valsa canker in apples is limited [4]. In our course of screening for anti-MRSA activity, we isolated a new indole-diterpenoid designated as JBIR-03 (1) from mycelium of Dichotomomyces cejpii var. cejpii NBRC 103559.

D. cejpii var. cejpii NBRC 103559 was cultured at $27^{\circ} \mathrm{C}$ for 14 days in 500-ml Erlenmeyer flasks each containing a solid medium consisting of $15 \mathrm{~g}$ oatmeal and $50 \mathrm{ml} \mathrm{V8}$ Mix Juice (Campbell Soup Company). The mycelium

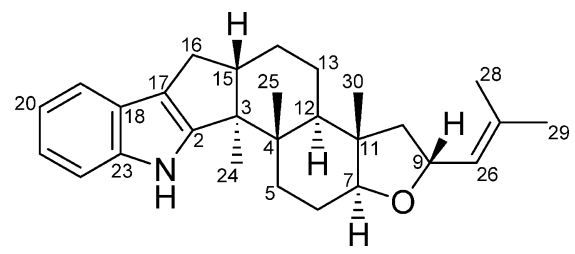

Fig. 1 Structure of JBIR-03 (1).
M. Ogata: Department of Microbiology, Faculty of Pharmaceutical Sciences, Aomori University; 2-3-1 Koubata, Aomori-shi, Aomori, 030-0943, Japan

T. Nakashima, K. Anzai: NITE Biological Resource Center (NBRC), National Institute of Technology and Evaluation (NITE), 2-5-8 Kazusakamatari, Kisarazu, Chiba 292-0818, Japan

M. Ogata, J. Ueda: These authors contributed equally to this work. 
Table 1 Physico-chemical properties of JBIR-03 (1)

\begin{tabular}{ll}
\hline Appearance & Colorless needle \\
MP & $142.5 \sim 148.0^{\circ} \mathrm{C}$ \\
{$[\alpha]_{D}^{24.5}$} & $+46.2^{\circ}(\mathrm{c} 0.05, \mathrm{MeOH})$ \\
$\mathrm{HR}$-ESI-MS $(\mathrm{m} / \mathrm{z})$ & \\
$\quad$ found & $404.2953(\mathrm{M}+\mathrm{H})^{+}$ \\
$\quad$ calcd & 404.2929 \\
UV $\lambda_{\max }\left(\mathrm{MeOH}^{+} \mathrm{nm}(\log \varepsilon)\right.$ & $229(4.42), 280(3.76)$ \\
IR $v_{\max }\left(\mathrm{CHCl}_{3}\right) \mathrm{cm}^{-1}$ & 3477 \\
\hline
\end{tabular}

$(500 \mathrm{ml} \times 8)$ was extracted with $80 \% \quad \mathrm{Me}_{2} \mathrm{CO}$. After concentration in vacuo, the residual concentrate was extracted with EtOAc $(200 \mathrm{ml} \times 3)$. After drying over $\mathrm{Na}_{2} \mathrm{SO}_{4}$, the organic layer was evaporated to dryness. The dried residue $(0.48 \mathrm{~g})$ was applied to normal-phase MPLC (Purif-Pack SI-60, Moritex) and developed with a $n$ hexane - EtOAc linear gradient system to yield an active fraction ( $40 \sim 55 \%$ EtOAc eluate). The active eluate was subjected to preparative reversed-phase HPLC $(90 \%$ $\mathrm{MeOH}-\mathrm{H}_{2} \mathrm{O}$, Senshu Pak PEGASIL ODS 20 i.d. $\times$ $150 \mathrm{~mm}$ ) to yield 1 (1.0 mg; Rt, 14.5 minutes).

The physico-chemical properties of $\mathbf{1}$ are summarized in Table 1. 1 was obtained as colorless needles (MP 142.5 $148.0^{\circ} \mathrm{C}$ ) and its molecular formula was determined to be $\mathrm{C}_{28} \mathrm{H}_{37} \mathrm{NO}$ by HR-ESI-MS. The IR $\left(v_{\max } 3477 \mathrm{~cm}^{-1}\right)$ and $\mathrm{UV}\left(\lambda_{\max } 229,280 \mathrm{~nm}\right)$ spectra of 1 suggested the presence of an indole moiety $[5,6]$. The ${ }^{1} \mathrm{H}$ - and ${ }^{13} \mathrm{C}$-NMR spectra (Table 2) revealed the signals of ten $s p^{2}$ carbons $\left(\mathrm{C}-2, \delta_{\mathrm{C}}\right.$ $151.9 ; \mathrm{C}-17, \delta_{\mathrm{C}} 117.8 ; \mathrm{C}-18, \delta_{\mathrm{C}} 126.0 ; \mathrm{C}-19 \delta_{\mathrm{H}} 7.28, \delta_{\mathrm{C}}$ $118.6 ; \mathrm{C}-20, \delta_{\mathrm{H}} 6.92, \delta_{\mathrm{C}} 119.6 ; \mathrm{C}-21, \delta_{\mathrm{H}} 6.95, \delta_{\mathrm{C}} 120.7 ;$ $\mathrm{C}-22, \delta_{\mathrm{H}} 7.28, \delta_{\mathrm{C}} 112.6 ; \mathrm{C}-23, \delta_{\mathrm{C}} 141.8 ; \mathrm{C}-26, \delta_{\mathrm{H}} 5.32, \delta_{\mathrm{C}}$ 127.7; C-27, $\left.\delta_{\mathrm{C}} 135.7\right)$, two oxygenated carbons (C-7, $\delta_{\mathrm{H}}$ $\left.3.30, \delta_{\mathrm{C}} 87.4 ; \mathrm{C}-9, \delta_{\mathrm{H}} 4.90, \delta_{\mathrm{C}} 75.1\right)$, two vinyl methyl groups $\left(\mathrm{C}-28, \delta_{\mathrm{H}} 1.68, \delta_{\mathrm{C}} 18.1 ; \mathrm{C}-29, \delta_{\mathrm{H}} 1.73, \delta_{\mathrm{H}} 26.0\right)$, and three methyl groups $\left(\mathrm{C}-24, \delta_{\mathrm{H}} 1.03, \delta_{\mathrm{C}} 15.0 ; \mathrm{C}-25, \delta_{\mathrm{H}}\right.$ $\left.1.11, \delta_{\mathrm{C}} 21.0 ; \mathrm{C}-30, \delta_{\mathrm{H}} 0.91, \delta_{\mathrm{C}} 15.4\right)$. In the ${ }^{1} \mathrm{H}-{ }^{1} \mathrm{H}$ COSY spectrum of 1 , spin couplings among aromatic protons 19$\mathrm{H}\left(\delta_{\mathrm{H}} 7.28\right), 20-\mathrm{H}\left(\delta_{\mathrm{H}} 6.92\right), 21-\mathrm{H}\left(\delta_{\mathrm{H}} 6.95\right)$ and $22-\mathrm{H}\left(\delta_{\mathrm{H}}\right.$ 7.28) revealed the presence of a 1,2-disubstituted benzene ring. The sequence from $10-\mathrm{H}\left(\delta_{\mathrm{H}} 1.97,1.25\right)$ through $9-\mathrm{H}$ $\left(\delta_{\mathrm{H}} 4.90\right)$ to $26-\mathrm{H}\left(\delta_{\mathrm{H}} 5.32\right)$ which in turn allylic coupled to methyl protons $28-\mathrm{H}\left(\delta_{\mathrm{H}} 1.68\right)$ and $29-\mathrm{H}\left(\delta_{\mathrm{H}} 1.73\right)$ established a 4-methylpent-3-en-2-ol moiety. In the same manner, a pentane and a propan-1-ol moiety were recognized. In the HMBC spectrum of $\mathbf{1}$, the aromatic proton $19-\mathrm{H}$ was peri coupled to aromatic quaternary carbon $\mathrm{C}-17\left(\delta_{\mathrm{C}} 117.8\right)$, which was further long-range coupled to methylene protons $16-\mathrm{H}\left(\delta_{\mathrm{H}} 2.61,2.29\right)$. In addition, 16-H was long-range coupled to an aromatic carbon C-2 $\left(\delta_{\mathrm{C}} 151.9\right)$. Taking into consideration these correlations and UV absorption vide supra, a 2,3disubstituted indole residue was established. ${ }^{1} \mathrm{H}-{ }^{13} \mathrm{C}$ longrange couplings between $16-\mathrm{H}$ and $\mathrm{C}-3\left(\delta_{\mathrm{C}} 53.9\right)$, between a methyl proton $24-\mathrm{H}\left(\delta_{\mathrm{H}} 1.03\right)$ and $\mathrm{C}-2, \mathrm{C}-3, \mathrm{C}-4\left(\delta_{\mathrm{C}}\right.$ 41.4) and $\mathrm{C}-15\left(\delta_{\mathrm{C}} 50.1\right)$, and between a methyl proton $25-$ $\mathrm{H}\left(\delta_{\mathrm{H}} 1.11\right)$ and $\mathrm{C}-3, \mathrm{C}-4, \mathrm{C}-5\left(\delta_{\mathrm{C}} 34.4\right)$ and $\mathrm{C}-12\left(\delta_{\mathrm{C}}\right.$ 47.6) elucidated the connectivity among these substructures as shown in Fig. 2A. Likewise, a methyl proton $30-\mathrm{H}\left(\delta_{\mathrm{H}}\right.$ $0.91)$ to $\mathrm{C}-7\left(\delta_{\mathrm{C}} 87.4\right), \mathrm{C}-10\left(\delta_{\mathrm{C}} 49.6\right), \mathrm{C}-11\left(\delta_{\mathrm{C}} 46.1\right)$ and $\mathrm{C}-12$ proved the tri-ring system. Finally, long-range couplings between the methylene proton $10-\mathrm{H}$ and $\mathrm{C}-7$, $\mathrm{C}-11$ and $\mathrm{C}-12$, and between an oxymethine proton $9-\mathrm{H}$ $\left(\delta_{\mathrm{H}} 4.90\right)$ and $\mathrm{C}-7$ established the tetrahydrofuran moiety. Thus, the planar structure of $\mathbf{1}$ was determined as shown in Fig. 2A.

The relative configuration was assigned on the basis of coupling constants and the analysis of a ROESY experiment measured in pyridine- $d_{5}$. The large coupling constants for $J_{6 \mathrm{H}, 7 \mathrm{H}}(11.7 \mathrm{~Hz})$ and $J_{14 \mathrm{H}, 15 \mathrm{H}}(10.5 \mathrm{~Hz})$ suggested that $7-\mathrm{H}$ and $15-\mathrm{H}$ are in axial location. The ROESY correlations (Fig. 2B) between 7-H, $5-\alpha \mathrm{H}, 10-\alpha \mathrm{H}$ and $12-\mathrm{H}$, and between $24-\mathrm{H}, 5-\alpha \mathrm{H}, 14-\alpha \mathrm{H}$ and $16-\alpha \mathrm{H}$ indicated these protons located the same direction. The ROESY correlations between $25-\mathrm{H}, 6-\beta \mathrm{H}, 13-\beta \mathrm{H}, 15-\mathrm{H}$ and $30-\mathrm{H}$, between $10-\beta \mathrm{H}, 9-\mathrm{H}$ and $30-\mathrm{H}$, and between $9-\mathrm{H}$ and $30-\mathrm{H}$ also revealed that $6-\beta \mathrm{H}, 9-\mathrm{H}, 10-\beta \mathrm{H}, 13-\beta \mathrm{H}, 15-$ $\mathrm{H}, 4-\mathrm{Me}(25-\mathrm{H})$ and $11-\mathrm{Me}(30-\mathrm{H})$ are in $\beta$-orientation. Thus, the structure of $\mathbf{1}$ was established as shown in Fig. 1. The structure of 1 resembled those of emindole SB [5] and paspaline [6], which were reported as indoloditerpenes except for the tetrahydrofuran moiety. Although lots of indolediterpenes such as emindole SB [5], paspaline [6], petromindole [7] and paxilline [8] were reported, the terminal ring system of these compounds commonly consisted of a 6-membered ring such as pyran. In contrast, the structure of 1 possessing the terminal ring system that consists of a 5-membered ring such as furan in this series of nodulisporic acids [9] is very rare.

1 was examined for antimicrobial activities against $S$. aureus N315, MRSA (S. aureus N315 $\Delta \mathrm{I}-\mathrm{HR})$, Bacillus subtilis JCM2499, Pseudomonas aeruginosa JCM5962, Escherichia coli IID 5208 and V. ceratosperma which is resistant to known antifungal compound such as griseofulvin. 1 inhibited the growth of Gram-positive and Gram-negative bacteria at concentrations of 32 and $64 \mu \mathrm{g} / \mathrm{ml}$, respectively. 1 also inhibited the growth of $V$. ceratosperma with an MIC value of $128 \mu \mathrm{g} / \mathrm{ml}$. To the contrary, $\mathbf{1}$ did not show any cytotoxic activity against a human HT-1080 fibrosarcoma cell line at a concentration of $100 \mu \mathrm{M}$. 
Table $2{ }^{13} \mathrm{C}(150 \mathrm{MHz})-$ and ${ }^{1} \mathrm{H}(600 \mathrm{MHz})-\mathrm{NMR}$ data for $\mathbf{1}$

\begin{tabular}{|c|c|c|c|}
\hline & ${ }^{13} \mathrm{C}^{\mathrm{a}}$ & ${ }^{1} \mathrm{H}^{\mathrm{a}}$ & ${ }^{1} \mathrm{H}^{\mathrm{b}}$ \\
\hline 2 & 151.9 & & \\
\hline 3 & 53.9 & & \\
\hline 4 & 41.4 & & \\
\hline \multirow[t]{2}{*}{5} & 34.4 & $1.94(\mathrm{~m})$ & $1.88(\mathrm{~m})$ \\
\hline & & $1.87(\mathrm{~m})$ & $1.79(\mathrm{~m})$ \\
\hline \multirow[t]{2}{*}{6} & 23.5 & $1.88(\mathrm{~m})$ & $1.82(\mathrm{~m})$ \\
\hline & & $1.78(\mathrm{~m})$ & $1.74(\mathrm{~m})$ \\
\hline 7 & 87.4 & $3.30(\mathrm{~m})$ & $3.28(d d, 11.7,1.8)$ \\
\hline 9 & 75.1 & $4.90(\mathrm{~m})$ & $4.94(q, 8.2)$ \\
\hline \multirow[t]{2}{*}{10} & 49.6 & $1.97(d d, 11.5,7.1)$ & $1.88(\mathrm{ddd}, 11.2,6.7,2.1)$ \\
\hline & & $1.25(\mathrm{~m})$ & $1.17(\mathrm{~m})$ \\
\hline 11 & 46.1 & & \\
\hline 12 & 47.6 & $1.74(\mathrm{~m})$ & $1.78(\mathrm{~m})$ \\
\hline \multirow[t]{2}{*}{13} & 26.4 & $1.58(\mathrm{~m})$ & $1.53(\mathrm{brq}, 12.5)$ \\
\hline & & $1.53(\mathrm{~m})$ & $1.41(\mathrm{~m})$ \\
\hline \multirow[t]{2}{*}{14} & 26.3 & $1.75(\mathrm{~m})$ & $1.75(\mathrm{~m})$ \\
\hline & & $1.67(\mathrm{~m})$ & $1.64(\mathrm{~m})$ \\
\hline 15 & 50.1 & $2.75(b r q, 10.5)$ & $2.79(\mathrm{~m})$ \\
\hline \multirow[t]{2}{*}{16} & 28.3 & $2.61(\mathrm{dd}, 12.9,6.5)$ & $2.76(\mathrm{~m})$ \\
\hline & & $2.29(\mathrm{dd}, 12.9,10.9)$ & $2.45(t, 10.6)$ \\
\hline 17 & 117.8 & & \\
\hline 18 & 126.0 & & \\
\hline 19 & 118.6 & $7.28(\mathrm{brd}, 7.9)$ & $7.55(\mathrm{~m})$ \\
\hline 20 & 119.6 & $6.92(\mathrm{brt}, 7.5)$ & $7.21(\mathrm{td}, 7.6,1.5)$ \\
\hline 21 & 120.7 & $6.95(\mathrm{brt}, 7.5)$ & $7.25(\mathrm{td}, 7.9,1.5)$ \\
\hline 22 & 112.6 & $7.28(\mathrm{brd}, 7.9)$ & $7.70(\mathrm{brd}, 7.6)$ \\
\hline 23 & 141.8 & & \\
\hline 24 & 15.0 & 1.03 (s) & $1.11(\mathrm{~s})$ \\
\hline 25 & 21.0 & $1.11(\mathrm{~s})$ & $1.38(\mathrm{~m})$ \\
\hline 26 & 127.7 & $5.32(\mathrm{dd}, 8.8,1.0)$ & $5.51(\mathrm{dd}, 8.5,1.2)$ \\
\hline 27 & 135.7 & & \\
\hline 28 & 18.1 & $1.68(\mathrm{~s})$ & 1.69 (s) \\
\hline 29 & 26.0 & 1.73 (s) & 1.62 (s) \\
\hline 30 & 15.4 & 0.91 (s) & 0.89 (s) \\
\hline
\end{tabular}

${ }^{\text {a }}$ Measured in methnol- $d_{4}$ including $4.0 \% \mathrm{CDCl}_{3}$. ${ }^{\mathrm{b}}$ Measured in pyridine- $d_{5}$.

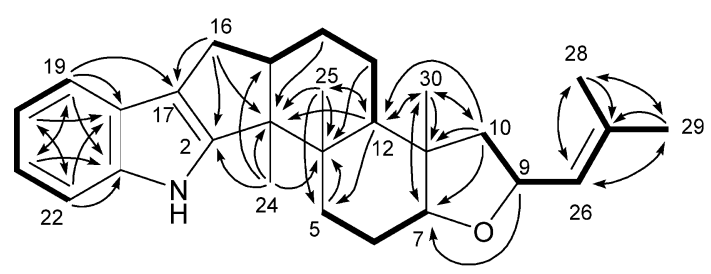

A

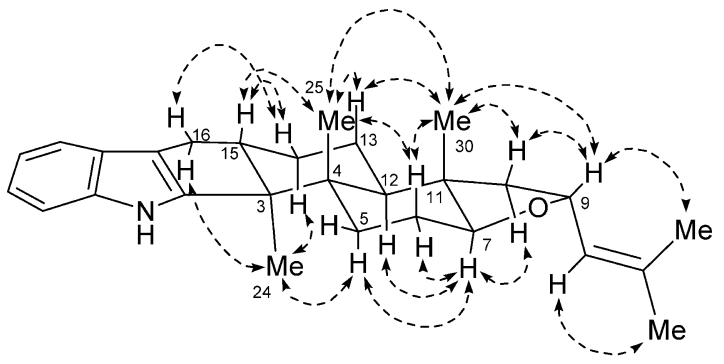

B ROESY:

Fig. 2 Key correlations in ${ }^{1} \mathrm{H}-{ }^{1} \mathrm{H}$ COSY (solid line) and $\mathrm{HMBC}$ (solid arrow, A), and ROESY experiments (dashed arrow, B) of 1 . 
Acknowledgement This work was supported by a grant from the New Energy and Industrial Technology Development Organization (NEDO) of Japan.

\section{References}

1. Livermore DM. $\beta$-Lactamases in laboratory and clinical resistance. Clin Microbiol Rev 8: 557-584 (1995)

2. Centers for Disease Control and Prevention. Staphylococcus aureus resistant to vancomycin-United States, 2002. Morb Mortal Wkly Rep 51: 565-567 (2002)

3. Sakuma T. Valsa canker. In Compendium of Apple and Pear Diseases. Ed., A. L. Jones, H. S. Aldwinckle, pp. 39-40, APS Press, St. Paul (1990)

4. Abe K, Kotoda N, Kato H, Soejima J. Resistance sources to Valsa canker (Valsa ceratosperma) in a germplasm collection of diverse Malus species. Plant Breeding 4: 449-453 (2007)

5. Nozawa K, Yuyama M, Nakajima, S, Kawai K, Udagawa S.
Studies on fungal products. part 19. Isolation and structure of a novel indoloditerpene, emindole SA, from Emericella striata. J Chem Soc, Perkin Trans 1: 2155-2160 (1988)

6. Fehr T, Acklin W. Die Ioslierung zweier neuartiger IndolDerivate aus dem Mycel von Claviceps paspali Stevens et Hall. Helv Chim Acta 49: 1907-1910 (1966)

7. Ooike M, Nozawa K, Udagawa S, Kawai K. Structures of a new type of indoloditerpene, petromindole, and a new asterriquinone derivative, PM-53, from the ascostromata of Petromyces muricatus. Chem Pharm Bull 45: 1694-1696 (1997)

8. Springer JP, Clardy J, Wells JM, Cole RJ, Kirksey JW. The structure of paxilline, a tremorgenic metabolite of Penicillium paxilli Bainier. Tetrahedron Lett 16: 2531-2534 (1975)

9. Singh SB, Ondeyka JG, Jayasuriya H, Zink DL, Ha SN, Dahl-Roshak A, Greene J, Kim JA, Smith MM, Shoop W, Tkacz JS. Nodulisporic acids D F: Structure, biological activities, and biogenetic relationships. J Nat Prod 67: 1496-1506 (2004) 